\title{
Socio - Economic and Psychological Profile of Farmers with Reference to Climate Change in Western Agro Climatic Zone of Tamil Nadu
}

\author{
B. Muthulakshmi* and Rajkumar Josmee Singh \\ Agricultural Extension, School Of Social Sciences, College of Post-Graduate Studies, \\ Barapani, 793102, Meghalaya, India \\ *Corresponding author
}

\begin{tabular}{|l|}
\hline Ke y w or d s \\
Climate change, \\
Socio-economic, \\
Fatalism
\end{tabular}

\section{A B S T R A C T}

Climate change is a major source of uncertainty for today's vulnerable farming societies and climate smart agriculture (CSA) is crucial for ensuring the food and livelihood security of any country and hence it is important that this sector becomes resilient to increasing climatic variabilities and changes. Keeping in view, the above considerations and exigency of vulnerability to climate change in agriculture for the state Tamil Nadu, the present research had been conducted with the objective to study the personal, socio-economic and psychological characteristics of farmers. Exploratory research design has been followed in the study. The Tamil Nadu state was purposively selected based on need and relevancy of the research problem. The study revealed that majority $(68.75 \%)$ of the farmers belonged to middle age group, had medium annual income (58.75\%), belong to medium social cohesiveness $(81.25 \%)$, had medium mass medium access $(72.50 \%)$, had medium knowledge on climate change $(83.75 \%)$. Having more percentage of respondents on medium and high level of fatalism as it was found in result hinted that there is need to develop competencies of farmers on consequences of climate change through the services of agricultural extensionists. Farmers need to have scientific temperament while mitigating and adapting climate change in agriculture. The farmers need to be educated on various proven mitigation and adaptation practices so as to build resiliency against the negative impact of climate change.

\section{Introduction}

Climate change is a change in the statistical distribution of weather patterns when that change lasts for an extended period of time. It is change in climate over time, whether due to nature's variability or as a result of human activity. Changes anticipated include heat waves, variability in the monsoons, droughts, floods, rise of sea level etc. These effects will lead to adverse effects on the people's lives leading exacerbating environmental degradation, reducing livelihood options, increasing migration from affected areas and worsening health and well-being, especially for the poorest of the poor and most marginalized communities. Climate change is likely to impact all natural ecosystems as well as socio-economic systems in India. In addition, poverty is a critical factor that limits the adaptive capacity of rural people in India. 
About $68.80 \%$ of rural population in our country is directly dependent on climate sensitive sectors such as agriculture, animal husbandry, fisheries etc. (Census, 2011).Since climate change is expected to impact natural and human systems adversely by inducing changes in these systems, India can be Considered highly vulnerable, as the extent of exposure is very high compared to most countries in the world.

During the period from 1901 to 2010, about $17 \%$ of years declared as drought years in India which resulted in severe impacts on agriculture, water resources, food security, economy and social life in the country. In the decade from 2002-2012, India was affected by three major droughts (viz., 2002, 2009 and 2012), with the 2012 drought causing $0.5 \%$ reduction in India's Gross Domestic Product (GDP), which is equivalent to US \$9 Billion (Manipadma, 2013).

International Panel on Climate Change (IPCC) has projected that by the end of the 21stcentury, overall rainfall in India will increase by $10-21 \%$ with more frequent and heavy rainfall days while the mean annual temperature will rise by $3-60^{\circ} \mathrm{C}$ (IPCC, 2012). Agriculture is one of the largest contributors to India's GDP sharing approximately $15 \%$. It is the main source of livelihood for almost $60 \%$ of the country's total population. The impacts of climate change on agriculture will therefore be severely felt in India.

Agriculture will be one of the sectors that will be hardest hit by adverse climate conditions, since agricultural production is extremely vulnerable to underlying climate risks such as drought, intense and erratic rainfall, and temperature shifts, which are a result of the intensification of the water cycle. Moreover, Climate change takes on agriculture is nearly incalculable and as result our food security is at risk.

\section{Materials and Methods}

In this study, the investigator has attempted to describe the socio-economic and psychological variables of the farmers. The study was conducted in western AgroClimatic Zone (ACZ) of Tamil Nadu state. The data collection related to this study was carried out in the year 2016. Exploratory research design has been followed in the study. The state Tamil Nadu was purposively selected based on need and relevancy of the research problem. Taking into consideration the agricultural importance and its vulnerability to climate change, two vulnerable districts viz., Theni and Dindigul districts of Western ACZ of the state were selected purposively. Again, Chinamanur C\&RD block and Attur C\&RD block were purposively selected. These two C\&RD blocks from the two identified districts were selected based on the criteria that they were the most agriculturally important blocks and also taken into consideration their geographical areas which fell within the Western ACZ. Subsequently, considering the agricultural importance and its vulnerability to climate change, two villages were selected from each identified C\&RD block. Hence, Appipatti and Odaipatti villages from Chinamanur C\&RD block, and Attur and Arkaraipatti villages from Attur C\&RD block were selected purposively. Altogether, a total of four villages were finalized for the study. Finally, proportionate random sampling was employed in selecting 80 farmers from the identified four villages in order to study their personal, socio-economic and psychological characteristics.

The variables are 'Age', 'Level of education', 'Operational land holding', 'Annual income', 'Mass media access', 'Knowledge of mitigation and adaptation of climate change practices in agriculture', were taken into consideration in the study. The psychological 
characteristics variables like 'Social cohesiveness', 'Awareness on consequences of climate change in agriculture', 'Perception on climate change in agriculture', and 'Fatalism', were administered to the respondents through five point likert scale mentioning strongly agree, agree, undecided, disagree and strongly disagree with the scoring pattern of 5,4,3,2 and 1 respectively. The distribution of scores were checked for normality by using 'One sample test of kurtosis and skewness' and it was found some of the variables were non-normal and therefore, the respondents had been divided into three groups viz., low, medium and high based on K-means cluster analysis. One sample test of kurtosis and skewness formulae

$$
\begin{aligned}
& z_{k}=\frac{K-0}{S E_{K}}, \text { where as } \mathbf{K}=\text { Value of kurtosis, } \\
& \mathbf{S E}_{\mathbf{K}}=\text { Standard error of kurtosis. }
\end{aligned}
$$

$z_{k=\frac{S k-0}{S E_{S k}}} ;$ whereas $\mathbf{S k}=$ Value of skewness, $\mathbf{S E}_{\mathbf{S k}}=$ Standard error of skewness. K-means clustering formulae

$I(V)=\sum_{i=1}^{c} \sum_{j=1}^{c i}\left(\left\|x_{i}-v_{j}\right\|\right)^{2}$

Where as $\left\|x_{i}-v_{j}\right\|$ - Euclidean distance between ${ }^{x_{i}}$ and $v_{j}, c_{i_{-}}$The number of data points in $i^{\text {th }}$ cluster, ' $C$ ' - The number of cluster centers.

\section{Results and Discussion}

\section{Socio-economic and psychological condition of farmers}

From table 1, majority of respondents come under the middle age group (68.75\%) followed by the old age group (17.50\%) and young age group (13.75\%). During data collection, it was observed that middle and old age group people intended to protect their natural resources and maintain their cultural practices in cultivation of crops and also interested to maintain their sustainable agriculture as compared to young age group and its similar to the findings Satishkumar $e t$ al., (2013). As found among the respondents, highest percentage of $28.28 \%$ of respondents passed higher secondary school followed by secondary school $(25.00 \%)$, graduate $(16.30 \%)$, upper primary $(12.50 \%)$, lower primary $(10.00 \%)$, literate but below primary $(5.00 \%)$ and illiterate $(2.50 \%)$ and the contradictory to the results as reported by Neethi (2014). This could reveal that the respondents were highly aware about effective use of information available to the respondent regarding climate change in the area. It is also observed that majority of respondents come under the middle income group (58.75\%) followed by high income group $(37.50 \%)$ and low income group (3.75\%). The present distribution of income group might be due to absence of full-fledged business opportunities on agriculture or farming in villages of the respondents. Non-remunerative subsistence farming/agriculture and allied activities was also a major observation during the study, followed by existence of lack of market infrastructure, market linkages and poor supply chain. The present findings were in contrast to findings as reported by Sathishkumar et al., (2013). Operational land holding revealed that majority of respondents were marginal farmers $(40.00 \%)$ followed by semi- medium farmers $(25.00 \%)$, small farmers $(20.00 \%)$, medium farmers $(10.00 \%)$ and large farmers $(5.00 \%)$. During the study it was observed that agricultural land become fragmented due to increase in population; thereby the very purpose of agriculture had been diverted to other non-agricultural purposes due to different interests of the owners.

Moreover, fast industrialization and urbanization enhanced usage of agricultural 
land for non-agricultural purposes. The findings were contrasted with the finding as reported by Idrisa et al., (2012). The psychological characteristic exposed that majority of respondents had medium level of social cohesiveness $(81.25 \%)$.

Followed by low level of social cohesiveness $(13.75 \%)$ and high level of social cohesiveness $(5.00 \%)$. This signified, and as observed during the study, that respondents had we feeling to some considerable extent while performing social activities, took collective decision during mitigation and adaptation of climate change in agriculture. Similar to findings as reported by Palmurugan et al., (2006). The variable exposure frequency of mass media access unveiled that majority of respondents had medium level of mass media access $(72.50 \%)$ followed by low (12.50\%) and high level of mass media access (15.00\%). Since the respondents were literate enough and were moderately versed with new ICT innovations and also regular contact of respondents with block level extension agents made the above distribution the finding of the study. The present findings were analogous to the findings as reported by Singh (2010).

Exactly half of respondents had high level of $(50.00 \%)$ awareness followed by low level $(42.50 \%)$ and medium level $(7.50 \%)$ of awareness on the consequences of climate change in agriculture. The bimodal distribution of respondents in the study might be due to poor social networks between the progressive/big farmers and the nonprogressive/marginal farmers. Progressive farmers were more involved and enthusiastic in agriculture and allied activities; thereby they had better mass media access and subsequently had more awareness on the consequences of climate change. Contrary nature had been observed on marginal farmers, they preferred more on wage labour job to agriculture. It was observed during the study that even the meager land what they possessed had been leased to other fellow farmers. Progressive farmers, as observed during the survey, did not share much of agricultural information to small or marginal farmers; they retained the information amongst themselves. The findings were analogous to the findings as reported by Idrisa et al., (2012).And also few per cent less than fifty per cent, that is, $48.75 \%$ and $46.25 \%$ of respondents had low level and high level perception on climate change which is followed by $5.00 \%$ or respondents who were in medium level. This bimodal distribution of respondents in case of awareness on consequences of climate change in agriculture. It could be observed during study that their existed poor social networks between the progressive/big farmers and the nonprogressive/marginal farmers. Progressive farmers were more aware on consequences of climate change in agriculture and allied activities, thereby they perceive climate change as a looming threat, contrary was the comment for the non-progressive/marginal farmers. Insignificant proportion of one twentieth of respondents had medium level of perception on negative consequences of climate change in agriculture. The result was parallel to the finding of Sahu and Mishra (2013). When "Knowledge on mitigation and adaptation practices in agriculture ${ }^{\text {ee }}$ by the respondents is studied, a very peculiar distribution of respondents, had been developed. Majority of $83.75 \%$ of the respondents had medium level followed by low level and high level which had been possessed by $15.00 \%$ and $1.25 \%$ of respondents. This might be due to medium level of mass media access by the respondents with respect to climate change adaptation and mitigation technologies. It was observed during the study that respondents did not acquire much knowledge/information on mitigation and adaptation practices in agriculture. 
Table.1 Distribution of respondents according to the personal, socio-economic and psychological characteristics $(\mathrm{N}=80)$

\begin{tabular}{|c|c|c|c|c|}
\hline S. No. & Variables & Categories & Frequency & Percentage \\
\hline \multirow[t]{3}{*}{1} & \multirow[t]{3}{*}{ Age } & Young Age Group & 11 & 13.75 \\
\hline & & Middle Age Group & 55 & 68.75 \\
\hline & & Old Age Group & 14 & 17.50 \\
\hline \multirow[t]{7}{*}{2} & \multirow[t]{7}{*}{ Level of education } & Illiterate & 2 & 2.50 \\
\hline & & Literate but below & 4 & 5.00 \\
\hline & & Lower Primary & 8 & 10.00 \\
\hline & & Upper primary & 10 & 12.50 \\
\hline & & Secondary School & 20 & 25.00 \\
\hline & & Higher Secondary School & 23 & 28.80 \\
\hline & & Graduate or higher & 13 & 16.30 \\
\hline \multirow[t]{3}{*}{3} & \multirow[t]{3}{*}{ Annual income } & Low Income Group & 3 & 3.75 \\
\hline & & Medium Income Group & 47 & 58.75 \\
\hline & & High Income Group & 30 & 37.50 \\
\hline \multirow{5}{*}{4} & \multirow{5}{*}{$\begin{array}{l}\text { Operational land } \\
\text { holding }\end{array}$} & Marginal (<1 Ha) & 32 & 40.00 \\
\hline & & Small $(>1-<2 \mathrm{Ha})$ & 16 & 20.00 \\
\hline & & Semi Medium $(>2-<4 \mathrm{Ha})$ & 20 & 25.00 \\
\hline & & Medium $(>4-<10 \mathrm{Ha})$ & 8 & 10.00 \\
\hline & & Large $(>10 \mathrm{Ha})$ & 4 & 5.00 \\
\hline \multirow[t]{3}{*}{5} & \multirow{3}{*}{$\begin{array}{l}\text { Social } \\
\text { cohesiveness }\end{array}$} & Low & 11 & 13.75 \\
\hline & & Medium & 65 & 81.25 \\
\hline & & High & 4 & 5.00 \\
\hline \multirow[t]{3}{*}{6} & \multirow[t]{3}{*}{ Mass media access } & Low & 10 & 12.50 \\
\hline & & Medium & 58 & 72.50 \\
\hline & & High & 12 & 15.00 \\
\hline \multirow[t]{3}{*}{7} & \multirow{3}{*}{$\begin{array}{l}\text { Awareness on the } \\
\text { consequences of } \\
\text { climate change in } \\
\text { agriculture }\end{array}$} & Low & 34 & 42.50 \\
\hline & & Medium & 6 & 7.50 \\
\hline & & High & 40 & 50.00 \\
\hline \multirow[t]{3}{*}{8} & \multirow{3}{*}{$\begin{array}{l}\text { Perception on } \\
\text { climate change }\end{array}$} & Low & 39 & 48.75 \\
\hline & & Medium & 4 & 5.00 \\
\hline & & High & 37 & 46.25 \\
\hline \multirow[t]{3}{*}{9} & \multirow{3}{*}{$\begin{array}{l}\text { Knowledge on } \\
\text { mitigation and } \\
\text { adaption practices } \\
\text { in agriculture }\end{array}$} & Low & 12 & 15.00 \\
\hline & & Medium & 67 & 83.75 \\
\hline & & High & 1 & 1.25 \\
\hline \multirow[t]{3}{*}{10} & \multirow[t]{3}{*}{ Fatalism } & Low & 16 & 20.00 \\
\hline & & Medium & 12 & 15.00 \\
\hline & & High & 52 & 65.00 \\
\hline
\end{tabular}


The finding was contradiction to the findings of Ogunleye and Yekinni (2012). The study could revealed that nearly two third $(65 \%)$ of respondents had high fatalism on climate change, followed by one fifth $(20.00 \%)$ and nearly one sixth $(16.00 \%)$ of respondents who had low and high level of fatalism. Even though good percentages of respondents were literate, there existed religious and cultural belief associated with agriculture. Conscientization about factors and consequences about climate change in agriculture by agricultural extension to the respondents/farmers was lacking. The result was dissimilar to the findings of Nkwusi et al., (2015)

In conclusion, the study revealed that majority $(68.75 \%)$ of the farmers belonged to middle age group, had medium annual income (58.75\%), belong to medium social cohesiveness $(81.25 \%)$, had medium mass medium access (72.50\%), had medium knowledge on climate change $(83.75 \%)$. The research asserted that bimodal distribution of respondents with respect to more percentage towards low and high categories in "Awareness on consequences of climate change in agriculture" and "Perception on climate change showed there was divide amongst the farmers on awareness and perception of consequences of climate change and mitigation and adaptation practices in agriculture and allied. Having more percentage of respondents on medium and high level of fatalism as it was found in result hinted that there is need to develop competencies of farmers on consequences of climate change through the services of agricultural extensionists. Farmers need to have scientific temperament while mitigating and adapting climate change in agriculture. The farmers need to be educated on various proven mitigation and adaptation practices so as to build resiliency against the negative impact of climate change. Effective extension strategies to network and sensitize the impact and consequences of climate change should be readily developed in consultation with scientists, researchers from universities, officials from state governments etc.

\section{References}

Census India. (2011). Literates and literacy rates by sex. Available at www.census2011.co.in/

Idrisa, Y.L., Ogunbameru, B.O., Irabhim, A.A., and Bawa, D.B. (2012). Analysis of awareness and adaptation to climate change among farmers in the Sahel Savannah Agroecological Zone of Borno State, Nigeria. Br. J. Enviro. Clim. Change., 2(2): 216-226.

IPCC, (2012). Managing the risks of extreme events and disasters to advance climate change adaptation in: Field, C.B., et al., (eds.) A special report of the intergovernmental panel on climate change. Cambridge University Press, Cambridge, UK, and New York, NY, USA, pp 582.

Manipadma, J. (2013). India strives to become "drought proof". The guardian. Available from: http://www.the guardian.com/environment/2013/mar/12 /indiastrives-drought-proof.

Neethi, B. (2014). Study of socio - economic profile of farmers in mahabubnagar district of Andhra Pradesh. Glob. j. Res. Analysis, 3(8): 4-7.

Nkwusi, G., Adeaga, S., Ayejuyo, S., and Annuk, A. (2015). Climate change; Farmers' awareness, perceptions and responses in Lagos State. Applied Ecology Environ. Sci., 3(4): 95-99.

Ogunleye, K.Y. and Yekinni, O.T. (2012). Crop farmer's knowledge level of climate change in Ilorin East Local Government Area of Nigeria. Developing Country Stud., 2(7): 6-13.

Palmurugan, M., Jhamtani, A., and Padaria, 
R.N. (2006). Entrepreneurial behavior of vanilla growers of Tamil Nadu and Kerala. Pusa. Agri. Sci., 29: 76-83.

Sahu, N.C. and Mishra, D. (2013). Analysis of perception and adaptability strategies of the farmers to climate change in Odisha.

Satishkumar, N., Tevari, P., and Singh, A. (2013). A Study on constraints faced by farmers in adapting to climate change in rainfed agriculture. J. Hum. Ecol., 44(1): 23-28.

Singh, R.J. (2010). Status of dairying in Manipur. Ph.D. Thesis, Submitted to National Dairy Research Institute, Karnal, Haryana, India.

\section{How to cite this article:}

Muthulakshmi, B. and Rajkumar Josmee Singh. 2018. Socio - Economic and Psychological Profile of Farmers with Reference to Climate Change in Western Agro Climatic Zone of Tamil Nadu. Int.J.Curr.Microbiol.App.Sci. 7(11): 2559-2565.

doi: https://doi.org/10.20546/ijcmas.2018.711.291 